\title{
Assessment of Chlorine Resistance Enterobacter cloacae Isolated from Water Storage Tanks in Sulaimaniyah City-Iraq
}

\author{
Hastyar H. Najmuldeen ${ }^{1} \& 2$ * \\ ${ }^{1}$ Department of Biology, College of Science, University of Sulaimani, Kurdistan Region, Iraq \\ ${ }^{2}$ College of Science, Komar University of Science and Technology, Sulaimani, Kurdistan Region, Iraq
}

Received 07 November 2020; revised 03 January 2021;

accepted 04 January 2021; available online 10 January 2021

doi: $10.24271 /$ psr.01

\begin{abstract}
This study was designed to determine the extent of contamination of water storage tanks by non-lactose fermenter Enterobacter spp, and to characterize the chlorine and antibiotic resistance status. Moreover, to find the correlation between biofilm formation and resistance to chlorine. For this purpose, a total of 60 water samples were collected from residential and restaurant water storage tanks. Bacterial analysis and antibiotic susceptibility profiles of the samples were assessed by the Most Probable Number (MPN) and Vitek 2 compact tests, respectively. The biofilm formation was quantified by crystal violet staining method and chlorine resistance test by microdilution technique. Obtained results indicated that water samples were contaminated by Escherichia coli (35\%). Additionally, water samples that were assessed to be potable by the MPN test showed that (44\%) positive for Enterobacter cloacae. Results of chlorine resistance test revealed variation in resistance of $E$. cloacae to different concentrations of chlorine, and relatively similar antibiotic susceptibility profiles. Moreover, biofilm analysis showed the isolates that were resistant to concentration of chlorine $400 \mathrm{mg} \mathrm{L}^{-1}$, have formed significantly more biofilm than those that were resistant to other concentrations. A positive non-linear correlation $(\mathrm{r}=0.72)$ was found between the degree of biofilm formation and the ability of isolates to resist different chlorine concentrations, and no correlation has been detected between antibiotic and chlorine resistance. It can be concluded that the presence of chlorine resistant $E$. cloacae in drinking water can pose a real public health threat. The routine microbial water analysis should be modified to include detection of nonlactosefermenter Enterobacter.
\end{abstract}

C 2021 Production by the University of Garmian. This is an open access article under the LICENSE

https://creativecommons.org/licenses/by-nc/4.0/

Keywords: MPN, Chlorine treatment and chlorine resistant, Antibiotic resistant, Water storage tanks, Enterobacter cloacae, Biofilm formation.

\section{Introduction}

Drinking water is essential for life, but it is also an excellent medium for transmission of numerous waterborne infections such as cholera, typhoid fever, infectious hepatitis, amoebic and bacillary dysentery ${ }^{[1]}$. Chlorination is the most commonly used treatment method for water safety $[2,3,4,5]$. However, many different species of bacteria are known to develop resistance to chlorine $[6,7,8]$. The increased prevalence of bacterial contamination of water storage tanks was linked to the loss of residual disinfectant activity and prolonged storage time ${ }^{[9,10,11]}$. The danger of contaminated water is not only restricted to the emergence of chlorine resistant bacteria, but chlorine resistance can lead to cross resistance to commonly used antibiotics ${ }^{[6,8,12]}$. Furthermore, the water distribution systems are known to harbor

* Corresponding author

E-mail address: hastyar.najmuldeen@univsul.edu.iq (Instructor).

Peer-reviewed under the responsibility of the University of Garmian. biofilms even in the continuous presence of disinfectants ${ }^{[13]}$. It is now accepted that microbial biofilms in drinking water distribution networks and water storage tanks can lead to the deterioration of water quality and pose a substantial threat to public health ${ }^{[14,15]}$. Biofilms protect contaminating bacteria and act as a potential reservoir for waterborne infections ${ }^{[2]}$.

International water quality standards depend mainly on the detection of total and fecal coliform Escherichia coli in pre- and post-chlorination ${ }^{[14,16]}$. While chlorination effectively eliminates fecal coliform E. coli. However, other microbial species including Enterobacter spp. and Citrobacter freundii have been reported to be detected post-chlorination, very likely these resistant microbes are harbored in biofilms on water pipes and tanks ${ }^{[16]}$. Alarmingly, some of these Enterobacter spp were found to be multidrug resistant (MDR), which can cause healthcare-associated infections ${ }^{[17]}$. A study conducted in the USA between 1995-2002, found that Enterobacter spp. are the significant cause of nosocomial bloodstream infections ${ }^{[16]}$. Two of the well- known Enterobacter spp, E. aerogenes and E. cloacae, are considered clinically important ${ }^{[18,19]}$. 
The provision of safe drinking water is one of the major challenges of the $21^{\text {st }}$ century ${ }^{[16]}$. Due to the water shortage, in Kurdistan and most of Iraqi cities, people rely on rooftop storage tanks, which are directly exposed to sunlight and provides suitable growth condition for bacteria. In Iraq, public health authorities assess the microbial content in water samples using the Most Probable Number (MPN) method. This method relies on detection of fecal coliform E. coli, and it does not take commonly found environmental contaminate Enterobacter spp. into consideration ${ }^{[20]}$. Therefore, the present study aimed to assess the extent of contamination by lactose fermenter $E$. coli and E. cloacae in water storage tanks in Sulaymaniyah city. Furthermore, the isolates of E. cloacae were characterised for chlorine and antibiotic resistance as well as for biofilm forming ability.

\section{Methods and Materials}

\subsection{Sample collection}

In most of Iraqi cities people can use water from both residential and restaurant water storage tanks. Sample collection was performed between August and September 2018, in which a total of 60 water samples were collected from residential tanks as private source and restaurant water storage tanks as a public source for daily uses of water in Sulaimaniyah city. Prior sample collection, water temperature was recorded in each storage tank. Then, after $3 \mathrm{~min}$ flushing water from tanks spigot, the samples $(200 \mathrm{ml})$ were collected in wide-mouth sampling bottles, labeled, kept in the ice box and transported to the laboratory at the directorate of health prevention hospital, Sulaymaniyah province / Kurdistan region / Iraq.

\section{2 Physicochemical analysis:}

Each water sample was subjected to physiochemical analysis for both $\mathrm{pH}$ and residual chlorine. $\mathrm{pH}$-meter was used for measuring $\mathrm{pH}$ value and free chlorine residual was measured using previously described iodometric titration method for determination of total and free chlorine ${ }^{[21]}$. All tests were performed in triplicates and the averages have been recorded.

\section{3 Microbiological water analysis:}

Microbial content analysis of water samples is based on detection of total coliform, fecal coliform Escherichia coli, enterococci and Clostridium perfringens ${ }^{[2]}$. According to drinking water guidelines, the qualified water for drinking should be with zero MPN result (0 cfu / $100 \mathrm{ml}-1)^{[22]}$. The Most Probable Number (MPN) test is a multiple-tube fermentation technique used to determine total coliform and fecal coliform in a water sample ${ }^{[16]}$. The coliform group of enteric bacteria can be detected on the basis of their ability to ferment lactose to acid and gas. In this study a single set of 5-tube MPN method was performed as recommend by the World Health Organization (WHO) and previously described standard protocols for total coliforms and fecal coliforms $[11,20]$. The decision on the presence of total coliform E. coli was made on the basis of three successive steps, consisting of a presumptive test (detection of total coliform), a confirmation test (detection of fecal coliform), and a completed test (detection of thermotolerant E. coli). In the first step five tubes of $10 \mathrm{ml}$ double-strength MacConkey broth (Fluka) was inoculated with $10 \mathrm{ml}$ of water sample and incubated for 24 hours at $37^{\circ} \mathrm{C}$. After incubation the presence of acid and gas in any tube was designated as a positive presumptive result. From the number of tubes with the positive acid and gas formation, the most probable number (MPN) of bacteria present in $100 \mathrm{ml}$ of original water sample was determined using the probability table provided by WHO to the water directorate of Sulaymaniyah city. For the second step (confirmation test) a $0.1 \mathrm{ml}$ from the positive tube of first step was transferred into a new single-strength MacConkey broth tube, and incubated for 24 hours at $44^{\circ} \mathrm{C}$. After incubation the growth was recorded as a positive fecal coliform. The final step (completed test) was performed through inoculation of Eosin Methylene Blue (EMB) agar (Fluka) plate and peptone broth from the positive growth of fecal coliform tube. Then, the samples were incubated for 24 hours at $35^{\circ} \mathrm{C}$ for peptone broth and $44^{\circ} \mathrm{C}$ for EMB agar. The result was considered positive thermotolerant E. coli when green metallic sheen colonies observed on EMB agar and red ring formed on top of peptone broth after addition of Kovac's reagent.

\section{4 Isolation and Identification of Enterobacter cloacae in negative MPN test:}

MPN test is not a suitable test to differentiate between fecal coliforms E. coli and Enterobacter spp. in contaminated water ${ }^{[20]}$. Therefore, this study was mainly focused on isolation of nonlactose fermenter bacteria in MPN negative results, which was considered as potable water and free of microbial contamination. To rule out the presence of non-lactose fermenter in all MPN negative water samples, the negative tubes of MPN test were subcultured on MacConkey agar (Fluka) and incubated at $37^{\circ} \mathrm{C}$ for 24 hours. Then, the well-isolated colonies of non-lactose fermenter bacteria from each MPN negative water sample were subjected to identification using Vitek-2 compact, biofilm formation assay, chlorine resistance test, and antibiotic sensitivity test (AST).

\section{5 Antibiotic susceptibility test:}

A loopful of E. cloacae from MacConkey agar were streaked on nutrient agar and the plates were incubated at $37^{\circ} \mathrm{C}$ for $24 \mathrm{~h}$. Then, a sufficient number of colonies from nutrient agar was suspended in $3 \mathrm{ml}$ sterile distilled water in order to obtain a turbidity level of 0.5-0.6 in McFarland scale (McFarland Densitometer, GrantBio). This bacterial suspension was used to determine the resistance patterns by the Vitek-2 Compact automated system (VITEK® 2: Healthcare, bioMérieux USA) using the AST-GN69 cards (VITEK $\AA 2$ Gram Negative Susceptibility Card) for the following antibiotics: amoxicillin/clavulanic acid, cefazolin, ceftazidime, ciftriaxone, cefepime, entrapenem, imipenem, gentamicin, tobramycin, ciprofloxacin, levofloxacin, nitrofurantoin, and trimethoprim /sulfamethoxazole. Furthermore, Kirby Bauer test Bauer et al. (1966) was also used for determination extra antibiotic sensitivity profiles, which was not found in AST-GN69 card used above ${ }^{[23]}$. Briefly, a sterile cotton swab was dipped into the microbial suspension and then it was streaked evenly across the surface of a Muller-Hinton agar plate. Within 15 minutes of inoculation, the antimicrobialcontaining disks (erythromycin $15 \mu \mathrm{g}$, rifampicin $5 \mu \mathrm{g}$, amikacin $30 \mu \mathrm{g}$, tetracycline $30 \mu \mathrm{g}$, and chloramphenicol $30 \mu \mathrm{g}$ ) (BIOMAXIMA company) were applied with sterile forceps, and 
the plates were incubated at $37^{\circ} \mathrm{C}$ for 18 hours ${ }^{[24]}$. Results were interpreted using the M100-S25 of Clinical and Laboratory Standards Institute guidelines, CLSI-guideline $2013^{[25]}$.

\section{6 In vitro determination of chlorine resistant bacteria:}

Chlorine resistant bacteria were determined by microtiter plate assay according to a procedure that is described by Huang et. al, (2011) with slight modifications [26]. According to the manufacturer's instructions, stock chlorine solutions were prepared from dichloroisocyanurate (NaC3N3O3CL2) (Chanelle Medical Limited Co, Ireland). Then, from stock chlorine solution, six different chlorine concentrations were prepared in sterile distilled water $0,25,50,100,200,300$, and $400 \mathrm{mg} \mathrm{L}-1$ and from overnight bacterial culture, bacterial suspension was separately prepared in sterilized distilled water $(1 \times 105 \mathrm{CFU} \mathrm{mL}-1)$. Then, to mimic the natural contact between chlorine concentrations and bacterial isolates, $2 \mu \mathrm{l}$ of bacterial suspension thoroughly mixed with $200 \mu \mathrm{l}$ of sterilized water (1:100 ratio) of each chlorine concentration using 96-microwell flat bottom polystyrene plates (SPL Plastic Labware, Korea).

The plate was incubated at room temperature for $30 \mathrm{~min}$ as previously described ${ }^{[6,27]}$. After 30 min of contact time between bacteria and chlorine concentrations, the bacterial survival was measured by triple spotting $20 \mu \mathrm{l}$ on Nutrient agar and incubated at $37^{\circ} \mathrm{C}$ for 18 hours. Growth of single colony and more per each $20 \mu \mathrm{l}$ spot was defined as resistant to chlorine. Then, to rule out the effect of high chlorine concentrations on water $\mathrm{pH}$, at the end of $30 \mathrm{~min}$ of bacterial exposure to different chlorine concentrations the $\mathrm{pH}$ and chlorine residual has been measured.

\section{7 In vitro determination of chlorine resistant bacteria:}

The quantitative crystal violet staining method was used to quantify the level of biofilm formation as described previously $[28,29,30]$. Fresh nutrient broth medium was inoculated 1:100 with $1 \times 10^{5} \mathrm{CFU} \mathrm{mL}^{-1}$ of E. cloacae. Then, a $200 \mu \mathrm{l}$ of this stock was transferred to the wells of 96-well flat bottom polystyrene plate (SPL Plastic Labware, Korea), and the plate was incubated in a static incubator at $37^{\circ} \mathrm{C}$ for $18 \mathrm{~h}$. The planktonic cells were removed and the wells were washed three times with $200 \mu \mathrm{l}$ PBS. After drying at room temperature for $30 \mathrm{~min}$, the biofilm was stained by addition of $200 \mu 10.5 \%$ (v/v) crystal violet at room temperature for $15 \mathrm{~min}$. Excess crystal violet was removed by washing three times with PBS. Stained biofilm in each well was dissolved in $200 \mu \mathrm{l}$ Ethanol:Acetone (80:20) (v/v). The absorbance of dissolved biofilm was measured at optical density (O.D) $595 \mathrm{~nm}$ using a microplate reader (Infinite F50 TECAN). The wells with uninoculated medium were used as control for crystal violet binding to the plastic.

\section{8 In vitro determination of chlorine resistant bacteria:}

GraphPad prism version 6 (Graphpad, California, USA) was used to analyze all data. One-way ANOVA and Tukey's multiple comparisons tests were used for statistical analysis. $p$ values less than 0.0001 was regarded as highly statistically significant. Pearson correlation coefficient was used to analyze correlation between the studied parameters, a $\mathrm{p}$ value of less than 0.05 was regarded statistically significant.

\section{Results and Discussion:}

According to the WHO, the mortality rate due to water-associated diseases exceeds 5 million people each year ${ }^{[16]}$. In Iraq, over the last two decades the provision of quantity and quality of water supplies has progressively declined. In 2014, a report published by the WHO revealed that the water supplies in Iraq are not adequate to prevent very likely widespread humanitarian crisis in the future ${ }^{[31]}$. In most Iraqi cities people consider the water from the distribution system is potable and safe to be collected in rooftop storage tanks. However, previous reports mentioned many sources of chemical and microbial contamination of domestic water due to direct discharge of untreated sewages and industrial wastewater into waterways and rivers, which eventually affects the human health ${ }^{[32]}$.

Results of physicochemical analysis of water from different storage tanks were showed that $\mathrm{pH}$ ranged from 6.8 to 7.5 , and temperature between 30 to $35{ }^{\circ} \mathrm{C}$. The free chlorine in storage tanks ranged from 0.01 to $1.12 \mathrm{mg} \mathrm{L}^{-1}$. The $\mathrm{pH}$ values in accordance with the WHO permissible limits $(6.5-8.5)^{[11]}$, and the temperature between $\left(30-35^{\circ} \mathrm{C}\right)$ during summer time (August and September), which is one of essential physical factor that determine microbial survival and growth in water storage tanks. It was reported that high temperature supports the growth of bacteria and fecal coliforms in storage tanks ${ }^{[11,33]}$.

Microbiological water analysis mainly focuses on detection of fecal indicator bacteria including enterococci and coliform group, especially E. coli ${ }^{[16]}$. The occurrence of total coliform bacteria was extensively determined in water storage tanks collected from residential and restaurant sources of Sulaimaniyah city. Obtained results exhibited that $1 / 3$ of water samples were contaminated by fecal coliforms E. coli ( $\mathrm{n}=21$ out of total 60 samples, $35 \%)$ and $2 / 3$ of samples with negative MPN results $(n=39$ out of total 60 samples, 65\%) (Figure-1A). Moreover, results of isolation and identification revealed that $44 \%(n=17$ positive out of 39 MPN negative) of water storage tanks were positive for E. cloacae and $56 \%$ ( $n=22$ negative out of 39 MPN negative) found negative (Figure-1B). This indicates the risk associated with the occurrence of E. coli, E. cloacae and other related non-lactose fermenter pathogenic bacteria dominant in water storage tanks, which is eventually increase the potential risk on people who are mainly dependent on water storage tanks. The problem of fecal E. coli contamination in water storage tanks is common in Bahir Dar, Ethiopia ${ }^{[34]}$, in Dubai by $45 \%{ }^{[1]}$ and in Bermuda by $66 \%$ ${ }^{[35]}$. Likewise, microbiological analysis of household water tanks exhibited contamination by non-lactose fermenter Pseudomonas aeruginosa, Salmonella gallinarum, and Enterobacter aerogenes ${ }^{[1]}$. The high percentages of water contamination by fecal coliform might be as a result of declining the quality of water in Dukan lake, which provides the major water supply to Sulaimaniyah city [36]. Moreover, the main water sources can easily get fecal coliforms as a result of leakage and contamination throughout water supply networks [11], improper cleaning and covering storage tanks might be additional factors related to contamination. 

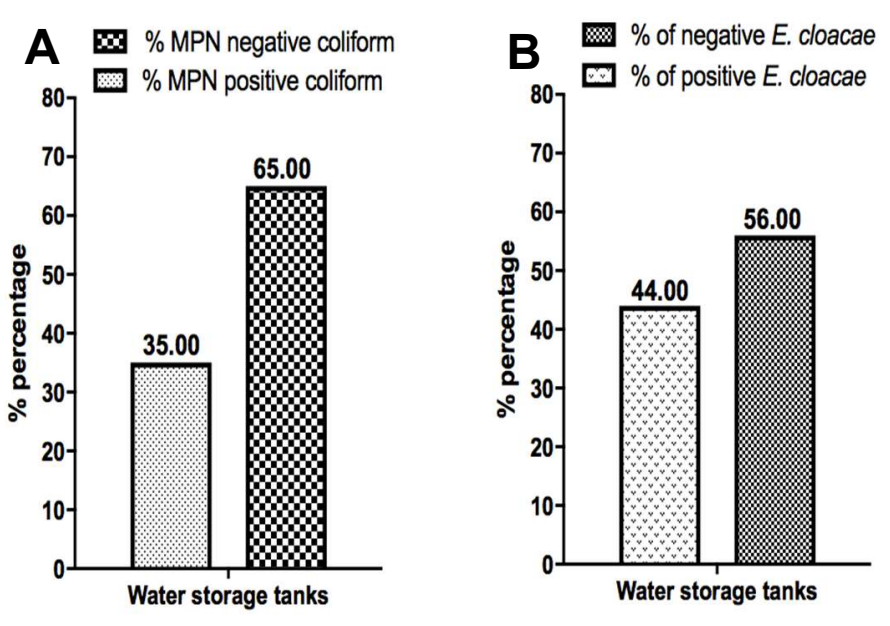

Figure 1: (A) Represents the results of MPN (Most probable Number) test for detection fecal coliform in water storage tanks $(n=21 / 60,35 \%$ positive) and ( $n=39 / 60,65 \%$ negative). The positive MPN test can be defined as the ability of fecal coliforms to ferment lactose into acid and gas. (B) Shows the percentage of E. cloacae growth on MacConkey agar isolated from negative MPN test. ( $n=17 / 39,44 \%$ positive) and ( $n=22 / 39,56 \%$ negative) growth of E. cloacae in water storage tanks.

\section{Determination of chlorine resistant Enterobacter cloacae:}

Although, chlorination is used as the main water treatment method in Kurdistan, it does no guarantee the safety of drinking water. According to previous study conducted in Sulaymaniyah city, while microbial content analysis of municipal storage tank did not show the presence of any contaminating bacteria, in the network and household samples, microbial growth could be demonstrated ${ }^{[37]}$. The present study has mainly focused on identification of E. cloacae and other related non-lactose fermenter pathogenic bacteria in water samples identified to be negative for coliforms using the MPN test. All E. cloacae isolates from both water sources $(n=17$ isolates out of 39 MPN negative water samples) were subjected to chlorine resistance test using different chlorine concentrations $(25,50,100,200,300$, and 400 $\mathrm{mg} \mathrm{L^{-1 }}$ ). Results of physiochemical analysis of six chlorine concentrations from initial and end of the experiment were exhibited that the $\mathrm{pH}$ ranged from (7.03 to 6.40) and residual chlorine after 30 min of contact time ranged from $(22,45,94$, 182, 283, and $384 \mathrm{mg} \mathrm{L}^{-1}$ ) (Table-1). Accordingly, results of chlorine resistance test classified E. cloacae isolate into six groups, 5 isolates exhibited resistance to $25 \mathrm{mg} \mathrm{L}^{-1}$ chlorine (G1), 3 isolates to $50 \mathrm{mg} \mathrm{L}^{-1}(\mathrm{G} 2), 4$ isolates to $100 \mathrm{mg} \mathrm{L}^{-1}(\mathrm{G} 3), 2$ isolates to $200 \mathrm{mg} \mathrm{L}^{-1}$ (G4), 1 isolate to $300 \mathrm{mg} \mathrm{L}^{-1}$ (G5), and 2 isolates (G6) were fully resistant to $400 \mathrm{mg} \mathrm{L}^{-1}$. It has been documented that chlorine rapidly inactivates coliforms and leaves chlorine resistant pathogens unaffected ${ }^{[16]}$. In consistence to these findings, recent study reported that lethal chlorine dose rapidly inactivates fecal coliforms $E$. coli but leaves chlorine resistant Enterococcus faecalis unaffected [38]. Likewise, Enterobacter spp. are the most frequently isolated microorganisms from tertiary treatment of wastewater ${ }^{[39]}$.

The presence of chlorine resistant bacteria in rooftop storage tanks might be attributed to the wide application of chlorine disinfectant for drinking water treatment. Moreover, in Sulaymaniyah and other Iraqi cities, the use of random concentrations of chlorine-containing substances in swimming pools might be directly linked to the development of super chlorine resistance isolates. In support to this explanation Destiani and Templeton (2019) reported that environmental isolates that have been previously exposed to chlorine may develop higher resistance to disinfectants ${ }^{[6]}$. As it was well described before, the frequent and overuse of sodium hypochlorite (NaOCL) has led to development of chlorine resistant bacteria ${ }^{[4,7]}$.

Table 1: Preparation and physiochemical analysis of different chlorine concentrations for bacterial chlorine resistance test. Each value represents the average of three independent experiment. (D.W: sterilize distillated water, $\mathrm{pH}: 7.1$ )

\begin{tabular}{|c|c|c|}
\hline $\begin{array}{c}\text { Initial chlorine } \\
\text { (mg L-1) in D. W }\end{array}$ & $\begin{array}{c}\text { Water } \mathrm{pH} \text { after } \\
\text { addition of } \\
\text { chlorine }\end{array}$ & $\begin{array}{c}\text { Residual free } \\
\text { chlorine (mg L-1) } \\
\text { after 30 min }\end{array}$ \\
\hline 0 & 7.1 & 0 \\
\hline 25 & 7.03 & 22 \\
\hline 50 & 6.91 & 45 \\
\hline 100 & 6.83 & 94 \\
\hline 200 & 6.69 & 182 \\
\hline 300 & 6.44 & 283 \\
\hline 400 & 6.40 & 384 \\
\hline
\end{tabular}

In the current study the most striking results is the ability of $E$. cloacae (G6: two isolates) to tolerate up to $400 \mathrm{mg} \mathrm{L}-1$ residual chlorine after $30 \mathrm{~min}$ contact time. Previous study reported that the genes involved in chlorine resistance are not from plasmid origin ${ }^{[4]}$. Therefore, the ability of E. cloacae to tolerate high concentration of chlorine might be attributed to the fact that chlorination will damage the vital functions of porins in bacterial outer membrane. It potentially reduces the cell permeability and increases the resistance to chlorine ${ }^{[6,18]}$. More recently Luo et al., (2020) emphasized that the resistant to chlorine is greatly attributed to cell permeability barriers and protective function of several genes that control oxidative stress, DNA repair, efflux pump, pore protein regulation and cell wall repair ${ }^{[40]}$. The ability of bacterial isolates to tolerate different concentrations of chlorine has been investigated by other researchers. Al-Berfkani et al., (2014) reported that Aeromonas hydrophilia, Staphylococcus aureus and Micrococcus varians resist 50, 100, $100 \mathrm{mg} \mathrm{L}^{-1}$ chlorine concentrations, respectively ${ }^{[41]}$. However, other studies stated that $10 \mathrm{mg} \mathrm{L}^{-1}$ of free chlorine is sufficient to kill all bacteria except Gram-positives and spore-forming bacteria $[42,43]$. These differences in chlorine resistance may be linked to differences in methods of chlorine resistance test, environmental conditions, and local treatment regimens.

\section{Biofilm formation:}

Previous studies emphasized that temperature, biofilm formation, and air greatly contribute in regrowth of different types of bacteria ${ }^{[1,44,45]}$. Results of biofilm formation was exhibited that G2 to G6 isolates formed significantly more biofilm than the G1 isolates $(p \leq 0.0001)$ (tableure-2). No significant differences in biofilm formation were noticed among G2 to G5 isolates $(\mathrm{p}>0.05)$. The highest biofilm was produced by G6 isolates, which were resistant to $400 \mathrm{mg} \mathrm{L}^{-1}$ of chlorine $(0.11 \pm 0.02)$, which is significantly higher than each of G3 and G4 $(0.086 \pm 0.006$ and $0.08 \pm 0.003$, respectively) $(\mathrm{p} \leq 0.001)($ Figure- 2$)$. 


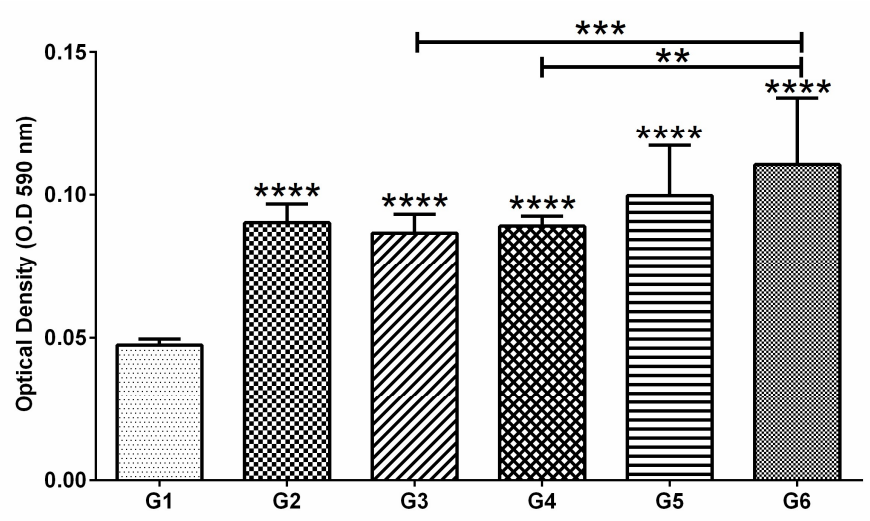

Figure 2: Evaluation of biofilm formation of E. cloacae strains by the crystal violet staining method. Data represent the Mean \pm SD (Standard deviation of the mean) of three independent experiments; each with triplicates. One-way ANOVA and Tukey's multiple comparison tests were used for statistical analysis $(* * * * \mathrm{P} \leq 0.0001)$. (G1) 5 isolates, (G2) 3 isolates, (G3) 4 isolates, (G4) 2 isolates, (G5) single isolate, and (G6) 2 isolates resistance to $25,50,100,200,300$, and $400 \mathrm{mg} \mathrm{L}^{-1}$, respectively.

This study also provides insight at the association between increased resistance to chlorine and biofilm formation ability of E. cloacae. Most importantly, moderate positive non-linear correlation ( $\mathrm{r}=0.722, \mathrm{n}=17$ isolates) was observed between the degree of biofilm formation and the ability of isolates to resist different concentrations of chlorine $(p>0.05)$. The overall trend in quantitative biofilm analysis showed that the degree of biofilm formation might be associated with the bacterial ability to resist the highest concentrations of chlorine. It has been well documented that production of exo-polysaccharide slime layer and biofilm formation restrict the diffusion of disinfectants into the inner layer of biofilm and may contribute to the survival of $P$. aeruginosa in chlorinated water [14, 15, 46, 47, 48]. Additionally, environmental factors such as temperature, $\mathrm{pH}$, pipe, and storage tank materials can strongly encourage the process of biofilm formation by chlorine-resistant community of Enterobacter spp. $[13,16]$. It has been defined that $E$. cloacae is able to form biofilms ${ }^{[18]}$. This could explain the increased resistance to chlorine as a result of biofilm formation, which is consistent with the results of Bertelli et al., (2018) who emphasized that the resistance of Pseudomonas to free chlorine is associated with their ability to form biofilm ${ }^{[14]}$. Similarly, recent study by Cai et al., (2018) showed that after $30 \mathrm{~min}$ exposure to chlorine dioxide and (200

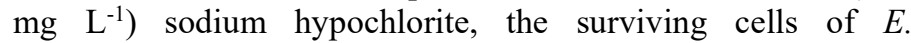
cloacae biofilms were found more resistant than the cells of Klebsiella oxytoca, and Citrobacter freundii biofilms [49]. Therefore, mechanism of chlorine resistance and its association with biofilm formation deserve to be studied in more detail in the future. Moreover, use of ozone or ultraviolet light as alternative methods for water treatment is highly recommended.

Table 2: Heatmap pattern of antibiotic resistance profiles of isolated E. cloacae strains ( $\mathrm{n}=17$ isolates) classified according to resistance to different concentrations of chlorine (G1:5 isolates, G2: 3 isolates, G3: 4 isolates, G4: 2 isolates, G5: single isolates, and G6: 2 isolates: are subgroups of resistant isolates to $25,50,100,200,300$, and $400 \mathrm{mg} \mathrm{L}^{-1}$ chlorine, respectively). ( $\square$ : Sensitive, $\square$ : Resistant, $\square$ : Intermediate). Inhibitors of cell wall synthesis: Ciftriaxone, Cefepime, Ertapenem, Ceftazidime, Imipenem, Cefazolin, Amoxicillin / clavulanic acid. Inhibitors of folic acid synthesis: Trimethoprim/Sulfamethoxazole. Inhibitors of protein biosynthesis: Gentamicin, Tobramycin, Chloramphenicol, Erythromycin. Inhibitors of DNA replication: Levofloxacin, Ciprofloxacin. Disrupt ribosomal RNA, DNA, others: Nitrofurantoin, Amikacin. Blocking the elongation of RNA: Rifampicin. Inhibitors of 30S subunit aminoglycosides: Tetracycline. Mode of antibiotics actions based on ${ }^{[50,51] .}$

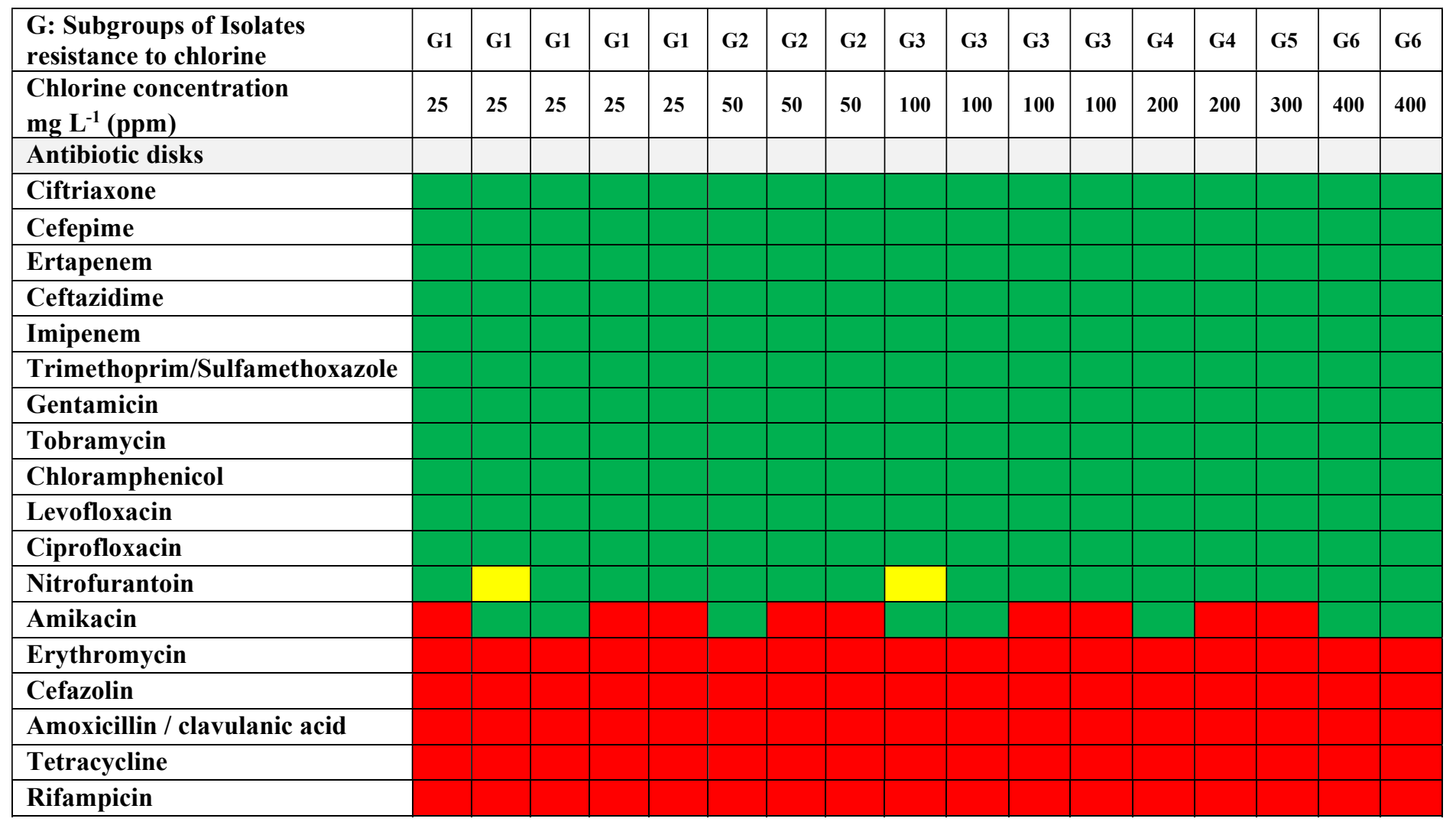




\section{Antibiotic susceptibility test:}

Residual chlorine was found to be the most important factor affecting the antibiotic resistance in treated water samples. Therefore, all chlorine resistance ( $\mathrm{G} 1$ to $\mathrm{G} 6, \mathrm{n}=17)$ isolates were analysed for resistance to 18 different antibiotics using Vitek compact- 2 and disc diffusion method recommended by CLSIguidelines ${ }^{[25]}$. The obtained results demonstrated that all chlorine resistant $E$. cloacae isolates were revealed sensitive to ciftriaxone, ceftazidime, ceftriaxone, cefepime $\beta$-lactam antibiotics of third and fourth generations cephalosporins, and other $\beta$-lactam classes ertapenem, imipenem. Similarly, sensitive to other classes of antibiotics with different mode of actions including triprthoprim / sulfamethoxazole, gentamicin, tobramycin, chloramphenicol, ciprofloxacin, levofloxacin, and nitrofurantoin (Table-2). However, the isolates were exhibited resistant to $\beta$-lactam antibiotics amoxicillin / clavulanic acid, first cephalosporin generation cefazolin, and other classes of antibiotic including erythromycin, tetracycline, and rifampicin (Table-2). Finally, a variable pattern of resistance and sensitivity were noticed to amikacin (Table-2). In consentience to this finding, many researchers confirmed that $E$. cloacae has a unique ability to acquire genes encoding resistance to multiple classess of antibiotics including $\beta$-lactamase inhibitor, aminoglycoside, tetracycline, and carbapenem ${ }^{[18,52,53,54,55,56,57,58,59]}$. It seems that continuous disposal of hospital waste, sewage, and other wastewater, all of which are potentially containing resistanceconferring genes, antibiotics, and their residual to the stream water, could serve as an essential contributing factor for environmental bacteria harboring antibiotic resistant ${ }^{[60,61,62]}$. It has been well documented that the occurrence of antibiotic resistant Enterobacteriaceae in sewage, treated drinking water, surface and river water can serve as an important reservoir for resistant genes of $\beta$-lactam antibiotics, carbapenems, tetracyclines, and chloramphenicol ${ }^{[27,62,63,64]}$ After $E$. coli and $K$. pneumoniae Davin-Regli and Pages (2015) described E. cloacae as the third broad spectrum Enterobacteriaceae species possessing extended spectrum $\beta$-lactamases (ESBL) and carbapenemases ${ }^{[18]}$.

So far, no clear physiological relation has been found between the mode of antibiotic action and resistance to different concentrations of residual chlorine. Results of the current study (Table-2) showed similar antibiotic resistance profiles of resistance $E$. cloacae to different concentrations of chlorine. This might be attributed to the fact all isolates were exposed to similar environmental stresses. The process of natural transformation might increase if the water contains residual chlorine and antibiotics from sewage water disposal. Recent study by Jin et al., (2020) explained that chlorine resistant bacteria are physiologically competent cells for higher plasmids transformation effeciency ${ }^{[38]}$. This concept has been confirmed by many researchers, Huang et al., (2011) and Murray et al., (1984) who suggested that chlorination helps development of antibiotic resistance strains through transference of resistanceconferring plasmids among bacteria in their natural environment $[26,65]$. However, contrary results of other studies found that chlorination did not significantly contribute to the resistance profile of E. coli strains [66, 67]. The lack of solid data on effectiveness of chlorination in reduction of antibiotic resistant bacteria requires further study to establish a link between antibiotic and chlorine resistance.

\section{Conclusion}

The water storage tanks in Sulaymaniyah city were contaminated by fecal $E$. coli and chlorine resistant E. cloacae. Chlorine disinfection cannot guarantee the complete removal and the risk of chlorine resistance bacteria in water distribution system and water storage tanks. Therefore, the threat of waterborne disease by $E$. cloacae might increase as the ability of this bacterium to produce biofilm appears to be positively correlated with the degree of chlorine resistance. Relatively similar antibiotic resistance profiles were found among all isolated E. cloacae. However, no correlation has been found between resistance to different chlorine concentrations and antibiotic resistance profiles. To control the potential risk posed by the waterborne pathogens and to reduce the false sense of safety, regular water quality assessment and widening the repertoire of tested indicator bacteria (non-lactose fermenter bacteria) are essential.

\section{Acknowledgment}

The author would like to thank Sulaymaniyah water directorate for providing laboratory facilities, and to the University of Sulaimani \& Komar University of Science and Technology, for providing continuous support during this work.

\section{References}

1. KHAN, M. A., \& ALMADANI, A. M. A. 2017. Assessment of microbial quality in household water tanks in Dubai, United Arab Emirates. Environ. Eng. Res. 22(1): 5560.

2. FARKAS, A., BOCOŞ, B., BULARDA, M. D. \& CRACIUNAS, C. 2014. Effect of different disinfectants against biofilm bacteria. Studia Universitatis Babes-Bolyai Biologia, LIX. 1: 5-20

3. LEVY, K., ANDERSON, L., ROBB, K. A., CEVALLOS, W., TRUEBA, G. \& EISENBERG J. N. 2014. Household effectiveness vs. laboratory efficacy of point-ofuse chlorination. Water Res. 54:69-77.

4. SHRIVASTAVA, R., UPRETI, R. K., JAIN, S. R., ORASAD K. N., SETH, P. K. \& CHATURVEDI, U. C. 2004. Suboptimal chlorine treatment of drinking water leads to selection of multidrug-resistant Pseudomonas aeruginosa. Ecotoxicol. Environ. Saf. 58(2): 277-283

5. SUN, W., LIU, W., CUI, L., ZHANG, M. \& WANG, B. 2013. Characterization and identification of a chlorine-resistant bacterium, Sphingomonas TS001, from a model drinking water distribution system. Sci. Total Environ. 458-460:169-175.

6. DESTIANI, R. \& TEMPLETON, M. R. 2019. Chlorination and ultraviolet disinfection of antibiotic-resistant bacteria and antibiotic resistance genes in drinking water. AIMS Environmental Science. 6(3):222-241.

7. KAMAL, M. A., KHALAF, M. A., AHMED, Z. \& JAKEE, J. E. 2019. Evaluation of the efficacy of commonly used disinfectants against isolated chlorine-resistant strains from drinking water used in Egyptian cattle farms. Vet. World. 12(12): 20252035.

8. SANGANYADO, E. \& GWENZI, W. 2019. Antibiotic resistance in drinking water systems: Occurrence, removal, and human health risks. Sci Total Environ. 669: 785797.

9. AKUFFO, I., COBBINA, S. J., ALHASSAN, E. H. \& NKOOM, M. 2013. Assessment of the quality of water before and after storage in the Nyankpala community of the Tolon-Kumbungu District, Ghana. IJSTR. 2(2):10-13.

10. BRICK, T., PRIMROSE, B., CHANDRASEKHAR, R., ROY, S., MULIYIL, J., \& KANG, G. 2004. Water contamination in urban south India: household storage 
practices and their implications for water safety and enteric infections. Int J Hyg Environ Health.5: 473-480.

11. CHALCHISA, D. MEGERSA, M. \& BEYENE, A. 2018. Assessment of the quality of drinking water in storage tanks and its implication on the safety of urban water supply in developing countries. Environ Syst Res. 6(12):1-6.

12. KAMPF, G. 2018. Biocidal agents used for disinfection can enhance antibiotic resistance in gram-negative species. Antibiotics. 7(4):1-24.

13. ZHU, Z., WU, C., ZHONG, D., YUAN, Y., SHAN, L. \& ZHANG, J. 2014. Effects of pipe materials on chlorine-resistant biofilm formation under long-term high chlorine level. Applied biochem Biotechnol.173 (6): 1-16.

14. BERTELLI, C., COURTOIS, S., ROSIKIEWICZ, M. \& et al. 2018. Reduced chlorine in drinking water distribution systems impacts bacterial biodiversity in biofilms. Front Microbiol. 9:1-11.

15. BRIDIER, A., BRIANDET, R., THOMAS, V. \& DUBOIS-BIOFOULING, F. 2011. Resistance of bacterial biofilms to disinfectants: a review. Biofouling. 27(9):10171032.

16. CABRAL, J. P. S. 2010. Water microbiology. Bacterial pathogens and water. Int. J. Environ. Res. Public Health. 7: 3657-3703.

17. KANAMORI, H., WEBER, D. J. \& RUTALA, W. A. 2016. Healthcare Outbreaks Associated with a Water Reservoir and Infection Prevention Strategies. Clin. Infect. Dis. 62(11):1423-1435.

18. DAVIN-REGLI, A. \& PAGÈS, J.-M. 2015. Enterobacter aerogenes and Enterobacter cloacae; versatile bacterial pathogens confronting antibiotic treatment. Front Microbiol. 6:1-10.

19. MEZZATESTA, M. L., GONA, F. \& STEFANI, S. 2012. Enterobacter cloacae complex: clinical impact and emerging antibiotic resistance. Future microbiol. 7(7): 887-902.

20. TALARO, K. P. and TALARO, A., 2002. Foundations in Microbiology, $4^{\text {th }}$ edit. The McGraw-Hill Companies. 810-811.

21. SAPUTRO, S., YOSHIMURA, K., TAKEHARA, K., MATSUOKA, S., NARSITO. 2011. Analytical methods of chlorine and the substances produced by the chlorine treatments, in: Chlorine Properties. Applications and Health Effects. pp. 259 274.

22. World Health Organization WHO, 2006. Guideline for drinking-water quality: incorporating first addendum recommendations, $3^{\text {rd }}$ ed. World Health Organization, Geneva.

23. BAUER, A.W., KIRBY, W.M., SHERRIS, J.C., TURCK, M., 1966. Antibiotic susceptibility testing by a standardized single disk method. Am. J. Clin. Pathol. 45:493-496.

24. MAHON, C. and MANUSELIS, G. 2000. Text book of diagnostic microbiology. $2^{\text {nd }}$ edition. W.B. Saunders Company.

25. CLSI, 2013. Performance Standards for Antimicrobial Susceptibility Testing; Clinical and Laboratory Standards Institute. https://doi.org/1-56238-525-5.

26. HUANG, J. J., HU, H. Y., TANG, F., LI, Y., LU, S. Q., \& LU, Y. 2011. Inactivation and reactivation of antibiotic-resistant bacteria by chlorination in secondary effluents of a municipal wastewater treatment plant. Water research. 45(9): 2775-2781.

27. YUAN, Q. B., GUO, M. T. \& YANG, J. 2015. Fate of antibiotic resistant bacteria and genes during wastewater chlorination: implication for antibiotic resistance control. PloS one. 1-11.

28. TENDOLKAR, P. M., BAGHDAYAN, A. S., GILMORE, M. S. \& SHANKAR, N. 2004. Enterococcal Surface Protein, Esp, Enhances Biofilm Formation by Enterococcus faecalis. Infect. Immun, 72 (10): 6032-6039.

29. SUO, Y., HUANG, Y., LIU, Y., SHI, C. \& SHI, X. 2012. The expression of superoxide dismutase (SOD) and a putative $\mathrm{ABC}$ transporter permease is inversely correlated during biofilm formation in Listeria monocytogenes 4b G. PLoS One. 7(10):1-9.

30. NAJMULDEEN, H., ALGHAMDI, R., ALGHOFAILI, F., YESILKAYA, H. 2019. Functional assessment of microbial superoxide dismutase isozymes suggests a differential role for each isozyme. Free Radic. Biol. Med. 134, 215-228.
31. World Health Organization WHO, 2014. Conflict and humanitarian crisis in Iraq, public health risk assessment and intervention.

32. ALWAN, A. 2004. Health in Iraq. Minister of Health, Iraq.1-80.

33. MUYIMA, N.Y.O., NGCAKANI, F. 1998. Indicator bacteria and regrowth potential of the drinking water in Alice, Eastern Cape. Water SA. 24: 29-34.

34. TABOR, M., KIBRET, M., ABER, B. 2011. Bacteriological and Physicochemical Quality of Drinking Water and Hygiene- Sanitation Practices of the Consumers in Bahir Dar City, Ethiopia. Ethiop. J. Health Sci. 21.(1):19-26.

35. TOKAJIAN, S. \& HASHWA, F. 2004. Microbiological quality and genotypic speciation of heterotrophic bacteria isolated from potable water stored in household tanks. Water Quality Research Journal. 39(1): 64-73.

36. ALOBAIDY, A.H.M.J., ABID, H.S., MAULOOD, B.K. 2010. Application of Water Quality Index for Assessment of Dokan Lake Ecosystem, Kurdistan Region, Iraq. $J$. Water Resour. Prot. 02, 792-798.

37. SALIH, F. A., OTHMAN, N., MUHIDIN, F. M. and KASEM, A. O. 2015. Assessment of the Quality of Water in Sulaimaniyah City, Kurdistan Region: Iraq. Curr. World Environ. 10(3): 781-791.

38. JIN, M., LIU, L., WANG, D. NING, YANG, D., LIU, W. LI, YIN, J., YANG, Z. WEI, WANG, H. RAN, QIU, Z. GANG, SHEN, Z. QIANG, SHI, D. YANG, LI, H. BEI, GUO, J. HUA, LI, J. WEN. 2020. Chlorine disinfection promotes the exchange of antibiotic resistance genes across bacterial genera by natural transformation. ISME J. 14 (7): 1847-1856.

39. LEONG, L. Y. C., OTSAKA, D. \& RIDGWAY, H. F. 1982. Chlorine-Resistance of Coliform-Tested Bacteria Isolated from Raw and Treated Sewage Effluents. Water Sci Tecnol. 14(4-5): 127-132.

40. LUO, L., WU, Y., YU, T., WANG, Y., CHEN, G., TONG, X., BAI, Y., XU, C., WANG, H., IKUNO, N., HU, H. (2020). Evaluating method and potential risks of chlorine-resistant bacteria (CRB): A review. Water Research, 188.

41. AL-BERFKANI, M. I., ZUBAIR, A. I. \& BAYAZED, H. 2014. Assessment of chlorine resistant bacteria and their susceptibility to antibiotic from water distribution system in Duhok province. J. appl. biol. biotechnol.2(6):10-13.

42. RIDGWAY, H. F. \& OLSON, B. H. 1982. Chlorine resistance patterns of bacteria from two drinking water distribution systems. Appl. Environ. Microbiol. 44(4): 972987.

43. SIMÕES, L., SIMÕES, M. \& VIEIRA, M. 2010. Influence of the Diversity of Bacterial Isolates from Drinking Water on Resistance of Biofilms to Disinfection. AEM. 76(19): 6673-6679.

44. AL-BAHRY, S. N., AL-HINAI, J. A. \& PROCEDIA, M.-I. Y. 2013. Opportunistic and microbial pathogens in municipal water distribution systems. APCBEE procedia. 5: 339-343

45. MEDRANO-FÉLIX, A., MARTINEZ, C., CASTRO-DEL, C.N, LEON-FELIX, J, PERAZA-GARAY, F. GERBA, C. P. \& CHAIDEZ, C. 2011. Impact of prescribed cleaning and disinfectant use on microbial contamination in the home. $J$ Appl. Microbiol. 110(2): 463-470.

46. GROBE, S., WINGENDER, J. \& FLEMMING, H-C. 2001. Capability of mucoid Pseudomonas aeruginosa to survive in chlorinated water. IJHEH. 204(2-3): 139-142.

47. LIN, H., ZHU, X., WANG, Y., YU, X. 2017. Effect of sodium hypochlorite on typical biofilms formed in drinking water distribution systems. JWH. 218-227.

48. PENNA, V., MARTINS, S. \& MAZZOLA, P. 2002. Identification of bacteria in drinking and purified water during the monitoring of a typical water purification system. BMC Public Health. 2(13):1-11.

49. CAI, L., WANG, H., LIANG, L., WANG, G., Xu, X., and WANG, H. 2018. Response of Formed-Biofilm of Enterobacter cloacae, Klebsiella oxytoca, and Citrobacter freundii to Chlorite-Based Disinfectants. Jfood science. 83 (5): 13261332.

50. BUSH, K., BRADFORD, P.A., 2016. $\beta$-lactams and $\beta$-lactamase inhibitors: An overview. Cold Spring Harb. Perspect. Med. 6 (8): 1-22. 
51. KAPOOR, G, SAIGAL, S., ElONGAVAN, A. 2017. Action and resistance mechanisms of antibiotics: A guide for clinicians. J Anaesthesiol Clin Pharmacol. 33(3):300-305.

52. ANNAVAJHAL, M.K., GOMEZ-SIMMONDS, A., Uhlemann, A.C. 2019. Multidrug-resistant Enterobacter cloacae complex emerging as a global, diversifying threat. Front. Microbiol. 10(44): 1-8.

53. BASSETTI, M., GINOCCHIO, F., MIKULSKA, M. 2011. New treatment options against gram-negative organisms. Crit. Care. 15:1-9.

54. GROSSMAN, T.H., 2016. Tetracycline antibiotics and resistance. Cold Spring Harb. Perspect. Med.6(4):a025387.

55. KEENEY, D., RUZIN, A., BRADFORD, P.A. 2007. RamA, a transcriptional regulator, and AcrAB, an RND-type efflux pump, are associated with decreased susceptibility to tigecycline in Enterobacter cloacae. Microb. Drug Resist. 13(1):1-6.

56. KIM, S.Y., Park, Y.J., Yu, J.K., Kim, Y.S., 2011. Aminoglycoside susceptibility profiles of enterobacter cloacae isolates harboring the aac(6')-Ib gene. Korean J. Lab. Med. 31: 279-281.

57. MOAWAD, A.A., HOTZEL, H., NEUBAUER, H., EHRICHT, R., MONECKE, S., TOMASO, H., HAFEZ, H.M., ROESLER, U., El-ADAWY, H.. 2018. Antimicrobial resistance in Enterobacteriaceae from healthy broilers in Egypt: Emergence of colistinresistant and extended-spectrum $\beta$-lactamase-producing Escherichia coli. Medical Mi. Gut Pathog. 10(39):1-12.

58. RAMOS, M.M.B., GAETTI-JARDIM, E.C., GAETTI-JARDIM, E. 2009. Resistance to tetracycline and $\beta$-lactams and distribution of resistance markers in enteric microorganisms and pseudomonads isolated from the oral cavity. J. Appl. Oral Sci. 17:13-18.

59. TANNER, W.D., VANDERSLICE, J.A., GOEL, R.K., LEECASTER, M.K., FISHER, M.A., OLASTADT, J., GURLEY, C.M., MORRIS, A.G., SEELY, K.A., CHAPMAN, L., KORANDO, M., SHABAZZ, K.A., STADSHOLT, A., VANDEVLDE, J., BRAUN-HOWLAND, E., MINIHANE, C., HIGGINS, P.J., DERAS, M., JABER, O., JETTE, D., GUNDLAPALLI, A. V. 2019. Multi-state study of Enterobacteriaceae harboring extended-spectrum beta-lactamase and carbapenemase genes in U.S. drinking water. Sci. Rep. 9. 3938.

60. AITURAIFI, F.H., ALMOMATIN, A.A., BADGER-EMEKA, L., EMEKA, P.M., ISLAM, M.M. 2019. Assessment of Microbiological Content of Private and Public Recreational Water Facilities and Their Antimicrobial Susceptibility Pattern in AlAhsa. Environ. Health Insights. 13:1-18.

61. MARTINEZ, J.L. 2009. Environmental pollution by antibiotics and by antibiotic resistance determinants. Environ. Pollut. 157(11):2893-902.

62. RTEDEL, S., BORIRE, N., CARSON, K.A., VADLMUDI, A., KHUVIS, J., VADLAMUDI, V., ATUKORALE, V., RIEDEL, V.A.A., PARRISH, N.M. 2019. A survey of antimicrobial resistance in Enterobacteriaceae isolated from the Chesapeake Bay and adjacent upper tributaries. Microbiologyopen. 8:1-14.

63. HUANG, J. J., HU, H., LU, S. Q., LI, Y., TANG, F. \& WEI, B. 2012. Monitoring and evaluation of antibiotic-resistant bacteria at a municipal wastewater treatment plant in China. Environ Int. 42:31-36.

64. KORZENIEWSKA, E., KORZENIEWSKA, A. \& HARNISZ, M. 2013. Antibiotic resistant Escherichia coli in hospital and municipal sewage and their emission to the environment. Ecotoxicol. Environ. Saf. 91: 96-102.

65. MURRAY, G. E., TOBIN, R. S., JUNKINS, B., \& KUSHNER, D. J. 1984. Effect of chlorination on antibiotic resistance profiles of sewage-related bacteria. AEM. 48(1): 73-77.

66. IWANE, T., URASE, T. \& YAMAMOTO, K. 2001. Possible impact of treated wastewater discharge on incidence of antibiotic resistant bacteria in river water. Water Sci Technol. 43(2): 91-99.

67. RIZZO, L., MANAIA, C., MERLIN, C., SCHWARTZ, T., DAGOT, C., PLOY, M. C., MICHAEL, I. \& FATTA-KASSINOS, D. 2013. Urban wastewater treatment plants as hotspots for antibiotic resistant bacteria and genes spread into the environment: A review. Sci Total Environ. 447: 345-360. 